\title{
The Use of Semipermeable Membrane Devices to Concentrate Chemicals in Oil Refinery Effluent on the Mackenzie River
}

\author{
JOANNE L. PARROTT, ${ }^{1}$ SEAN M. BACKUS,${ }^{2}$ ANNE I. BORGMANN ${ }^{3}$ and MURRAY SWYRIPA ${ }^{4}$
}

(Received 6 October 1997; accepted in revised form 12 October 1998)

\begin{abstract}
To concentrate natural and refinery-derived inducers of mixed function oxygenase (MFO), semipermeable membrane devices (SPMDs) were deployed for 11-12 days in Norman Wells refinery effluent and upstream and downstream on the Mackenzie River, Northwest Territories, Canada. SPMDs, which are layflat polyethylene membrane tubes containing a thin film of purified triolein, absorb freely dissolved neutral organic chemicals that diffuse through the polyethylene membrane. Fish liver cells (Poeciliopsis lucida hepatoma; PLHC-1) were dosed with SPMD extracts; then MFO activity was determined. SPMDs from the effluent contained potent MFO inducers, equivalent to 4830-8700 pg 2,3,7,8-tetrachlorodibenzo- $p$-dioxin (TCDD)/g SPMD. SPMDs from the site $0.5 \mathrm{~km}$ downstream of the refinery outfall also induced MFO, but downstream extracts were about $1 / 40$ as potent as those from effluent-exposed SPMDs. Comparing sites on the Mackenzie River, extracts of SPMDs from downstream of the refinery outfall were over 20 times as potent as those from upstream SPMDs. Polyaromatic hydrocarbons (PAHs) and C1- to C3-substituted PAHs were abundant in extracts of SPMDs from the effluent and, to a lesser degree, in extracts of SPMDs from $0.5 \mathrm{~km}$ downstream. In effluent-exposed and downstream SPMDs, concentrations of parent PAHs were lower than those of $\mathrm{C} 1$-substituted PAHs. The highest concentrations were those of $\mathrm{C} 2$ - and $\mathrm{C} 3$-substituted PAHs. It is unknown which compounds in the SPMDs caused the MFO induction, but there was a very strong correlation between the concentration of total C3-phenanthrene/anthracene in the SPMD extracts and MFO-induction potency. The study shows both the use of SPMDs as concentrators of neutral organic compounds in harsh environments (such as high temperature effluents and fast-flowing rivers) and the utility and sensitivity of the fish liver cell line for ranking MFO-inducing potencies of environmental SPMD extracts.
\end{abstract}

Key words: semipermeable membrane devices (SPMDs), mixed function oxygenase (MFO), Ethoxyresorufin-O-deethylase (EROD), oil refinery effluent, Mackenzie River, Norman Wells, cell line, PLHC-1, polyaromatic hydrocarbons (PAHs)

RÉSUMÉ. Afin de concentrer les inducteurs naturels et dérivés de raffinerie de l'oxygénase à fonction mixte (OFM), on a déployé de l'équipement à membrane semi-perméable pendant une durée de 11 à 12 jours dans les effluents de l'usine de raffinage de Norman Wells, de même qu'en amont et en aval dans les eaux du Mackenzie (Territoires du Nord-Ouest, Canada). Ces systèmes, formés de tubes de membrane en polyéthylène aplatis contenant une mince pellicule de trioléine purifiée, absorbent abondamment les produits chimiques organiques neutres en solution qui se diffusent dans toute la membrane de polyéthylène. On a mis des extraits de cette membrane en contact avec des cellules de foie de poisson (hépatocarcinome de Poeciliopsis lucida; HCPL-1), puis on a déterminé l'activité de l'OFM. Les membranes provenant des effluents contenaient de puissants inducteurs d'OFM, équivalents à 4830-8700 pg de tétrachlorodibenzodioxine- $p$ 2,3,7,8 (TCDD)/g de membrane. Les membranes provenant du lieu situé à $0,5 \mathrm{~km}$ en aval du déversoir étaient aussi des inducteurs d'OFM, mais environ quarante fois moins puissants que ceux provenant des membranes exposées directement aux effluents. En comparant les sites sur le Mackenzie, les extraits des membranes situées en aval du déversoir de la raffinerie étaient environ 20 fois plus puissants que ceux des membranes situées en amont. Les hydrocarbures aromatiques polycycliques (HAP) et les HAP de remplacement de formule $\mathrm{C} 1$ à $\mathrm{C} 3$ se trouvaient en abondance dans les extraits de membrane provenant des effluents et, à un degré moindre, dans les extraits de membrane provenant du lieu situé à $0,5 \mathrm{~km}$ en aval. Dans les membranes exposées aux effluents et aux eaux situées en aval, les concentrations des HAP mères étaient inférieures à celles des HAP de remplacement de formule $\mathrm{C} 1$. Les concentrations les plus fortes étaient celles des HAP de remplacement de formule $\mathrm{C} 2$ et $\mathrm{C} 3$. On ne sait pas quels composés présents dans les membranes ont causé l'induction de l'OFM, mais il existait une très forte corrélation entre la concentration totale de phénanthrène/anthracène dans les extraits de membrane et la puissance d'induction de l'OFM. L'étude démontre à la fois l'utilisation des membranes comme concentrateurs des composés organiques neutres dans un environnement difficile (tel celui d'effluents à haute température et de cours d'eau rapides) ainsi que l'utilité et la sensibilité de la lignée cellulaire de foie de poisson pour classer les extraits de membrane environnementale selon leur puissance d'induction de l'OFM.

\footnotetext{
${ }^{1}$ National Water Research Institute, 867 Lakeshore Rd., Burlington, Ontario L7R 4A6, Canada; joanne.parrott@cciw.ca

${ }^{2}$ National Laboratory for Environmental Testing, National Water Research Institute, 867 Lakeshore Rd., Burlington, Ontario L7R 4A6, Canada

${ }^{3}$ AIB BioQuest, 395 Swanson Court, Burlington, Ontario L7R 4G6, Canada

${ }^{4}$ Water Resource Division, Department of Indian Affairs \& Northern Development, 4914 - 50 Street, Yellowknife, Northwest Territories X1A 2R3, Canada; present address: Diavak Diamond Mines, Box 2498, Yellowknife, Northwest Territories X1A 2P8, Canada (C) The Arctic Institute of North America
} 
Mots clés: équipement à membrane semi-perméable, oxygénase à fonction mixte (OFM), éthoxyrésorufine-O-déséthylase (EROD), effluents du raffinage du pétrole, fleuve Mackenzie, Norman Wells, lignée cellulaire, HCPL-1, hydrocarbures aromatiques polycycliques (HAP)

Traduit pour la revue Arctic par Nésida Loyer.

\section{INTRODUCTION}

Mixed function oxygenases (MFOs) are a family of enzymes that aid in the excretion of nonpolar lipophilic endogenous and exogenous compounds (Martin et al., 1985). MFO enzymes increase in activity (referred to as induction) from constitutive to maximum levels, as a function of the dose of an inducing agent such as 2,3,7,8tetrachlorodibenzo- $p$-dioxin (TCDD; Greenlee and Poland, 1978; Okey, 1990; Parrott et al., 1995a). A number of chemical classes are known inducing agents: polyaromatic hydrocarbons (PAHs) and polychlorinated dibenzo- $p$ dioxins (PCDDs), dibenzofurans (PCDFs), and biphenyls (PCBs; Poland and Knutson, 1982; Okey, 1990).

Usually, MFO enzymes are quantified by catalytic assays that measure the reaction rate or activity of enzyme present. Liver cell extracts or cells in culture are incubated in a reaction mixture containing substrates that can be metabolized by MFO enzymes. The most recognized MFO enzyme assays are aryl hydrocarbon hydroxylase $(\mathrm{AHH})$ and ethoxyresorufin-O-deethylase (EROD), principally because of the simplicity of the assay system.

Increased MFO activity is a detoxification response that signals an organism's exposure to potentially toxic compounds. While the purpose of MFO is to protect the organism, long-term exposure to persistent organic anthropogenic chemicals may significantly elevate the level of these enzymes, producing detrimental effects. These include increased conversion of promutagens into their active mutagenic forms and increased oxidation of endogenous compounds, which causes metabolic disturbances.

MFO induction can often serve as an early warning signal of more serious pathologies (Payne et al., 1987). Few data directly support a mechanistic link between MFO and other health effects in fish. But in field studies of fish populations exposed to pulp mill effluents, elevated MFO activity often occurs in conjunction with decreased levels of circulating steroids and with physiological disturbances, such as enlarged liver, reduced gonad growth, and delayed sexual maturity (Munkittrick et al., 1991). MFO is also commonly elevated in livers of wild fish near natural oil seeps, oil rigs, oil refineries, and oil spills (reviewed in Payne et al., 1987). Enzyme activity in livers of wild or caged fish or in fish liver cells exposed to environmental extracts can be measured to screen for biologically active compounds such as PAHs (reviewed in Parrott et al., 1999).

In the Northwest Territories, the Mackenzie River flows through the Norman Wells Oil Field and receives effluent from an oil refinery. Because of these natural and anthropogenic hydrocarbon sources, questions have been raised regarding the effects of PAHs from the oil field on fish in the area. Observations by Native fishermen of watery and tainted fish flesh and poor-quality fish livers sparked research into the causes of inferior quality in fish caught in the area. Burbot (Lota lota) exposed to Norman Wells crude oil showed increased hepatic MFO activities, and wild burbot had tissues containing low-boiling-point aromatic hydrocarbons, with concentrations greater in winter than in summer (Lockhart et al., 1987). Small, dark livers with low fat content were apparent when fish were held under starvation conditions, similar to those in the Mackenzie River under ice, but liver alterations were not seen in oil-dosed fish (Lockhart et al., 1987). However, small trout exposed to the water-soluble fractions of crude oil refused food and became emaciated (Lockhart et al., 1996). It is unclear whether chemicals from natural seepage of oil and from the refinery effluent were causing tainting and biological effects in fish, or whether natural factors were causing the perceived decrease in fish quality.

The Norman Wells refinery produces oil (about $5000 \mathrm{~m}^{3} /$ day) and discharges cooling water and effluent $\left(2500 \mathrm{~m}^{3} /\right.$ day) into the Mackenzie River, which flows $\left(3500-25000 \mathrm{~m}^{3} / \mathrm{sec}\right)$ northwest through the town of Fort Good Hope to the Arctic Ocean. The central processing facility in the plant separates oil, gas, and water. Hot wastewater is held in aerated ponds, and skimmer booms recover floating hydrocarbon films before discharge to the Mackenzie River. Hydrocarbon contamination of the Mackenzie River could originate in the effluent stream or from oil deposits under the river disturbed by drilling. Visible signs of natural oil seeps in the area are the pools of oil and bubbles of natural gas that can be seen in local creeks.

Testing the receiving areas in the Mackenzie River is difficult because of high current and harsh conditions. Rather than launch a large-scale field survey, we used semipermeable membrane devices (SPMDs) to determine the types of chemicals potentially bioavailable to fish in the area.

SPMDs are layflat polyethylene tubes containing a thin film of triolein that have been used to concentrate organic compounds from air, water, soil, and sediments (reviewed in Huckins et al., 1996). Neutral organic chemicals can pass through the polyethylene membrane and partition into the lipid. In water, freely dissolved neutral organics are concentrated by SPMDs in much the same way that these compounds are taken up across the gill membrane of a live fish. For this reason SPMDs have been used as "surrogate fish." SPMDs provide a time-integrated, representative sample of effluent or river water. Such samples 


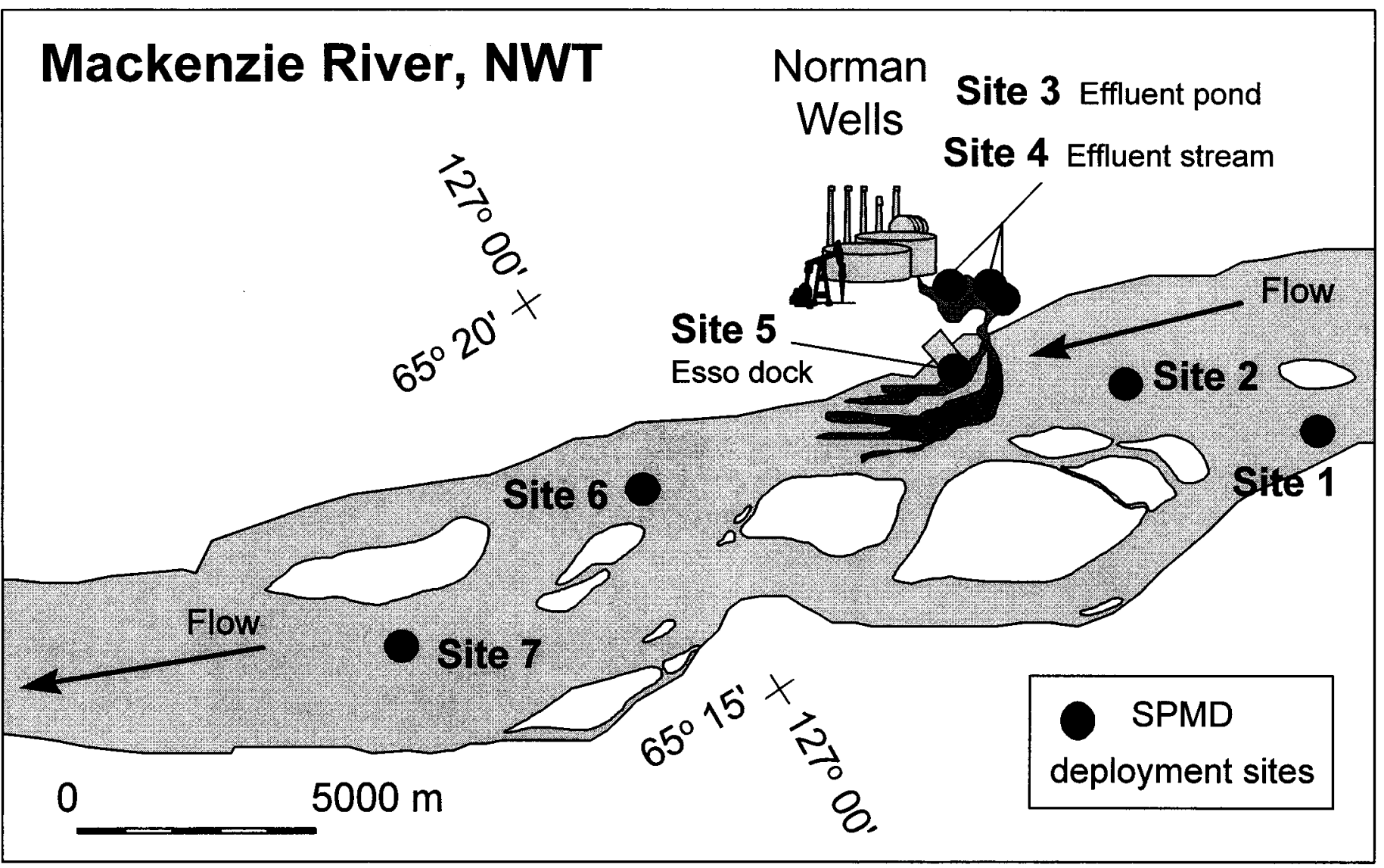

FIG. 1. Schematic map of the Mackenzie River in the Norman Wells area (NWT) showing the locations of SPMD deployment sites, September to October 1995.

are less vulnerable than grab samples to changes due to pulses of chemicals and different processes within industrial facilities. Another advantage is that they can be deployed in any environment: they withstand extremes of temperature and $\mathrm{pH}$ and strong currents, where fish could not survive for long periods. However, SPMDs cannot mimic the metabolism and excretion of compounds by fish, or the uptake of contaminants into a fish via food. SPMDs reflect the subset of compounds that fish may concentrate from water.

Traditionally, SPMD extracts have been used for chemical analysis: to back-calculate the concentrations of compounds in water, to determine bioavailable organic chemicals, and to compare concentrations in SPMDs to those in fish tissue, mussels, or other biota used for monitoring purposes (Huckins et al., 1990, 1996; Prest et al., 1995; Rohr et al., 1996). The use of SPMDs as concentrating devices for biological testing is relatively new, although research is expanding the types of tests used and applications of the technique. SPMDs have been successfully used to concentrate toxicants and mutagens from urban stream water, Antarctic sediments, $\mathrm{PAH}$-spiked sediments, and naturally contaminated sediments (Huckins et al., 1995a, 1996; Johnson, 1995; Johnson et al., 1995; Metcalfe et al., 1995).

Analysis of SPMD extracts by MFO assays using in vitro cell culture was first initiated by Don Tillitt of the Midwest Science Center, Columbia, Missouri (Huckins et al., 1996). SPMDs have been used to concentrate MFOinducing chemicals from pulp mill effluents; from oil sands, mining, and refining wastewaters; and from river and stream waters naturally high in PAHs (Parrott et al., 1996a,b; Villeneuve et al., 1997).

Examining the chemical composition of the SPMD extracts can give information about the types of compounds available to fish. Comparing the chemistry to the MFO-induction potency of the SPMD extracts can provide information on potential MFO inducers from effluents and from upstream and downstream waters.

In the present study, SPMDs were used to examine PAHs in the Mackenzie River and in effluent from the Norman Wells oil refinery. SPMD extracts were analyzed for parent and substituted PAHs, to see what types of compounds were bioavailable and present in MFO-inducing extracts. Extracts of SPMDs were tested for potency of MFO induction in a fish (Poeciliopsis lucida, a top minnow) hepatoma cell line, PLHC-1. Increased EROD activity in PLHC-1 indicated that MFO inducers were present in the SPMD extracts; therefore, they were present in the effluent or river water and were potentially bioavailable to fish. The MFO-inducing potency of extracts was compared with the concentrations of PAHs and substituted (C1-, C2- and C3-) PAHs present in the SPMD extracts to suggest candidate compounds responsible for the observed MFO induction. 


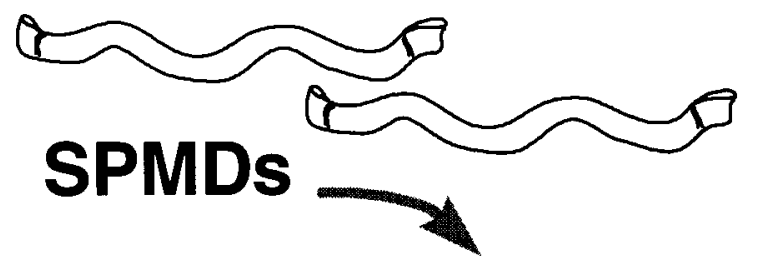

Two SPMDs in one wire basket at each site on Mackenzie River.

One basket in refinery effluent ponds, two baskets in refinery effluent stream.

11 to 12 days in Mackenzie River or in refinery effluent

Bring SPMDs back to the lab.

Solvents are used to remove chemicals from inside the SPMDs.

Exposure Clean up 4

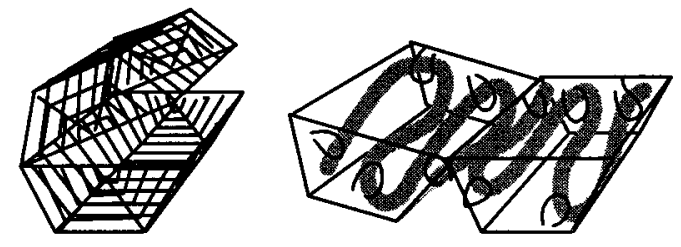
Extraction $48 \mathrm{~h}$ hexane dialysis $\downarrow$

Extract is concentrated to $1.0 \mathrm{~mL}$ Concentration

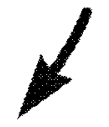

Test extract for MFO induction EROD activity in PLHC-1 cells

Fish liver cells grown in culture are exposed to the extracts. MFO induction is measured as EROD activity in the liver cells.

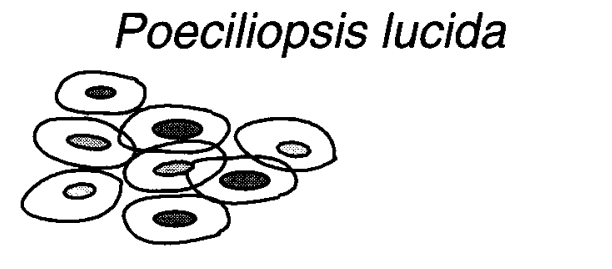

FIG. 2. Strategy for testing MFO inducers in oil refinery effluent and Mackenzie River.

In the SPMD extracts, it was important to examine and quantify the C1- to C3-substituted PAHs along with the routinely analyzed parent unsubstituted PAHs. In oilcontaminated environments, $\mathrm{C} 1$ - to $\mathrm{C} 3$-substituted PAHs are often present at much higher concentrations than their corresponding parent PAH (Yunker and MacDonald, 1995). Patterns of PAHs in SPMDs from upstream, downstream, and effluent sites were examined to determine the "background" of natural PAHs from weathering of the oil-rich substrate in the Mackenzie River, compared to anthropogenic PAH input from the Norman Wells refinery effluent.

\section{METHODS}

SPMDs were deployed in Mackenzie River waters upstream and downstream of the refinery outfall, as well as in the refinery wastewater pond and in the effluent stream (Fig. 1). SPMDs were left to concentrate MFO inducers over the 11- or 12-day exposure period, and then were removed and shipped to labs for processing and testing
(Fig. 2). The dissolved compounds in the SPMDs were extracted with solvents and concentrated to small volumes. The extracts were dosed to fish liver cells (PLHC1, Poeciliopsis lucida hepatoma cells, a liver tumour cell line from a top minnow) for $72 \mathrm{~h}$. MFO was then determined in the fish liver cells by measuring the EROD activity. Potency of extracts was compared to that of 2,3,7,8-tetrachlorodibenzo- $p$-dioxin (TCDD) as a standard inducing compound. Increased EROD activity indicated that MFO inducers were present in the SPMD extract and hence were present in the effluent or water and potentially bioavailable to fish. Chemical analysis of the SPMD extract was used to identify compounds that were freely dissolved in the water and were potentially bioavailable to fish, and classes of compounds present that could be responsible for MFO induction.

\section{Sampling Sites}

Five SPMD deployment sites were sampled on the Mackenzie River, and two in the refinery skimmer pond outflow and effluent stream (Fig. 1). Upstream sites on the 
TABLE 1. Latitude and longitude of SPMD deployment sites on the Mackenzie River in the area of Norman Wells (NWT), September to October 1995. The last column indicates approximate distance (in $\mathrm{km}$ ) of each SPMD deployment site from the Norman Wells refinery outfall. Sites with negative $\mathrm{km}$ values are upstream of the refinery, and those with positive $\mathrm{km}$ values are downstream.

\begin{tabular}{llc}
\hline \hline Site & Latitude and Longitude & $\begin{array}{l}\text { Distance from } \\
\text { Refinery }(\mathrm{km})\end{array}$ \\
\hline 1 (upstream) & $65^{\circ} 13^{\prime} 58.6^{\prime \prime} \mathrm{N}, 126^{\circ} 44^{\prime} 06.7^{\prime \prime} \mathrm{W}$ & -7 \\
2 (upstream) & $65^{\circ} 15^{\prime} 29.9^{\prime \prime} \mathrm{N}, 126^{\circ} 47^{\prime} 45.9^{\prime \prime} \mathrm{W}$ & -3 \\
3 (effluent pond) & not done & 0 \\
4 (effluent stream) rep 1 not done & 0 \\
4 (effluent stream) rep 2 not done & 0 \\
5 (downstream) & $65^{\circ} 16^{\prime} 45.2^{\prime \prime} \mathrm{N}, 126^{\circ} 52^{\prime} 31.9^{\prime \prime} \mathrm{W}$ & 0.5 \\
6 (downstream) & $65^{\circ} 17^{\prime} 38.7^{\prime \prime} \mathrm{N}, 126^{\circ} 59^{\prime} 49.3^{\prime \prime} \mathrm{W}$ & 7 \\
7 (downstream) & $65^{\circ} 17^{\prime} 46.1^{\prime \prime} \mathrm{N}, 127^{\circ} 07^{\prime} 23.5^{\prime \prime} \mathrm{W}$ & 12 \\
\hline \hline
\end{tabular}

river were 7 and $3 \mathrm{~km}$ above the refinery outfall, and downstream sites were $0.5,7$, and $12 \mathrm{~km}$ below the outfall (Table 1). One deployment device containing two SPMDs was used at each upstream and downstream site on the Mackenzie River. One deployment device containing two SPMDs was used in the refinery effluent pond, and two devices, each containing two SPMDs, were used in the final refinery effluent stream that enters the Mackenzie River (Fig. 1). At each site, two SPMDs were used as trip blanks: they were exposed to air, handled as if deployed, and then returned to the sealed can. The sampling was done from 20 September to 3 October 1995, at water temperatures of $10-11^{\circ} \mathrm{C}$. SPMDs were left in the water for 11 days (effluent samples) or 12 days (Mackenzie River samples).

\section{SPMD Deployment}

The SPMDs, purchased from Environmental Sampling Technologies (St. Joseph, Missouri), were low-density polyethylene layflat tubes $(91 \mathrm{~cm}$ long $\times 2.5 \mathrm{~cm}$ wide; wall thickness $0.80 \mu \mathrm{m})$ filled with $1 \mathrm{~mL}(0.915 \mathrm{~g})$ high-purity (95\%) synthetic triolein. SPMDs, sealed in tins, were sent to the field site at ambient temperatures. Several precautions were taken to prevent contact of SPMDs with contaminated field equipment. One person deployed the SPMD and handled only the deployment device and the SPMDs, while another person controlled the boat. Gloves were used while handling SPMDs and deployment devices. The deployment was performed as quickly as possible to reduce exposure to air and contaminants during handling. Trip blank SPMDs were open to the air for the same amount of time and were handled in the same manner as deployed SPMDs. When deployment was finished, trip blanks were returned to their sealed cans.

SPMDs were tied into metal baskets weighted with $1 \mathrm{~kg}$ iron balls (Fig. 2). The assembled deployment cages were tied to channel marker buoys in the Mackenzie River or set in the effluent stream or pond of the refinery. Water temperature, conductivity, and $\mathrm{pH}$ were measured at the time of each deployment or retrieval.

\section{SPMD Retrieval}

All deployed SPMDs were retrieved at the end of the exposure period (11 days for refinery effluent SPMDs and 12 days for Mackenzie River SPMDs). The retrieved SPMDs were wiped with a tissue to remove biofilm and immediately placed back in the clean cans and sent to the laboratory, where they were held frozen until analyzed. While several sites had SPMDs that withstood high currents, the changeable, harsh climate typifies the challenges of research in near-arctic environments. SPMDs at two of the three downstream sites were shredded or punctured, probably by abrasion of the membranes against the wire deployment basket in the highly turbulent current. Consequently, we have no SPMD data for sites 6 and 7, which were 7 and $12 \mathrm{~km}$ downstream of the Norman Wells refinery outfall. There was no vandalism or interference with field deployments of SPMDs in this study, as is sometimes the case. The extract of SPMDs from site 2 upstream was accidentally compromised in the clean-up phase, so no MFO potency data are available for that site.

\section{Water Characteristics}

Water temperatures, conductivity, and $\mathrm{pH}$ were higher in the effluent than in the river water at the deployment sites. In the river water, temperatures were from 9.9$11.4^{\circ} \mathrm{C}$, conductivity was $188-215 \mu \mathrm{S}$, and $\mathrm{pH}$ was $7.02-$ 7.13. In the effluent, temperatures were from $48-49.5^{\circ} \mathrm{C}$, conductivity was $490 \mu \mathrm{S}$, and $\mathrm{pH}$ was $7.08-7.27$.

\section{SPMD Clean-up, Dialysis, and Extract Concentration}

After the SPMDs were thawed, substances fouling the external membrane surface were removed by scrubbing the SPMDs with a toothbrush in a stainless steel tray containing cold tap water. Each membrane device was rinsed twice (first with methanol and then with hexane) and air-dried for approximately two minutes on solventwashed aluminum foil. Membrane(s) were placed in $500 \mathrm{~mL}$ (one device) or $1 \mathrm{~L}$ (two devices) amber glass jars, which were then filled with pesticide-grade hexane (approximately $400 \mathrm{~mL} / \mathrm{SPMD}$ ) and capped with Teflonlined lids. The SPMDs were dialysed for 48 hours in an incubator at $17^{\circ} \mathrm{C}$. The samples were gently agitated every $12 \mathrm{~h}$ to disrupt stagnant diffusional layers that might form. After $48 \mathrm{~h}$, the SPMDs were removed from the dialysate and discarded.

The dialysate was rotary-evaporated to about $5 \mathrm{~mL}$ and filtered into a centrifuge tube through a microcolumn of anhydrous sodium sulphate. The eluent was concentrated to $1 \mathrm{~mL}$ using a temperature- and pressure-controlled nitrogen evaporator (N-EVAP, Organomation, Berlin, MA). Compounds of interest were separated from residual triolein with size-exclusion, high-pressure liquid chromatography (HPLC). An isocratic mobile phase of 80:20 
hexane/dichloromethane was employed. The chromatographic column was $250 \times 21.2 \mathrm{~mm}$ of phenogel (Phenomenex, Torrance, California) adsorbent. The flow rate of the mobile phase was $4 \mathrm{~mL} / \mathrm{min}$ for one hour. The initial 27 minutes of eluent were discarded, and the remaining chromatographic solution was rotary-evaporated to approximately $5 \mathrm{~mL}$. The concentrates were transferred to centrifuge tubes and solvent exchanged with isooctane to a volume of $1 \mathrm{~mL}$. A subsample of $100 \mu \mathrm{L}$ was removed for chemical analyses. Another $100 \mu \mathrm{L}$ aliquot of extract was serially diluted for dosing fish cells for the EROD assay.

\section{Determining MFO Activity in the Fish Liver Cell Line}

SPMD extracts were tested for EROD induction potency in Poeciliopsis lucida hepatoma cells (PLHC-1). The PLHC-1 bioassay procedures were a slight modification of the H4IIE bioassay methods described in Tillitt et al. (1991), adapted for 96-well microtitre plates in which EROD activity is determined fluorometrically. PLHC-1 cells were incubated in $75 \mathrm{~cm}^{3}$ flasks (Corning) at $30^{\circ} \mathrm{C}$ with a $5 \% \mathrm{CO}_{2}$ atmosphere. Culture medium was prepared with Minimum Essential Medium with Earle's salts and Lglutamine, plus 5\% Fetal Bovine Serum, 1\% nonessential amino acids (100×), with $1 \%$ Penicillin/Streptomycin and $1 \%$ Fungizone antibiotics. The PLHC- 1 cells were seeded at 50000 cells/well in $500 \mu \mathrm{L}$ of culture medium. After a $24 \mathrm{~h}$ incubation, the cells were dosed with sample extracts or standards in a $5 \mu \mathrm{L}$ volume of isooctane. The cells were exposed to eight different concentrations (doses) of the samples in a $25 \%$ dilution series, with three replicates at each dose.

After $72 \mathrm{~h}$ exposure of the cells to SPMD-extracts, the medium was aspirated from each well and replaced with $150 \mu \mathrm{L}$ of a mixture of Tris buffer $(0.05 \mathrm{M}, \mathrm{pH} 7.8), \mathrm{NaCl}$ $(0.1 \mathrm{M})$ and 7 -ethoxyresorufin ( $2 \mu \mathrm{M}$ final concentration). The production of resorufin was measured fluorometrically (Cytofluor 2300, Millipore Ltd.; $530 \mathrm{~nm}$ excitation filter, $590 \mathrm{~nm}$ emission filter; sensitivity 3 ), once directly after the addition of the substrate mixture and again 10 minutes later. A resorufin standard curve $(0-425.17$ picomoles/ well) was prepared and measured along with samples. The samples were calibrated against 2,3,7,8-tetrachlorodibenzo- $p$-dioxin (TCDD) standards dosed at eight concentrations $(0,6.25,12.5,25,50,100,200,400 \mathrm{pM})$, with each dose replicated three times.

Protein was determined in the cells with an adaptation of the fluorescamine method of Lorenzen and Kennedy (1993). The substrate mixture was aspirated from each well and replaced with $250 \mu \mathrm{L}$ deionized-distilled water. The plates were frozen $\left(-80^{\circ} \mathrm{C}\right)$ for at least one hour prior to the protein assay. After thawing in a $30^{\circ} \mathrm{C}$ incubator, $500 \mu \mathrm{L}$ potassium phosphate buffer $(0.054 \mathrm{M} ; \mathrm{pH} 8.0)$ was added to each well, and the plates were placed on a shaker for 1 minute. Five minutes after the addition of $250 \mu \mathrm{L}$ fluorescamine $(0.27 \mathrm{mM}$ final concentration, dissolved in acetonitrile), fluorescence was measured (400 nm excitation filter; $460 \mathrm{~nm}$ emission filter; sensitivity 3 ). A bovine serum albumin (BSA) standard curve $(0-200 \mathrm{mg} /$ well $)$ was prepared and measured along with samples.

The doses of each sample ( $\mu \mathrm{L}$ SPMD extract/well) or TCDD standards (pg TCDD/well) were plotted against EROD activity ( $\mathrm{pmol} / \mathrm{mg}$ cellular protein/min) to develop dose-response curves. The initial linear portion of each curve was analyzed to determine the slope. TCDD-equivalents (pg TCDD-EQ/g SPMD) were calculated by sloperatio assay (Finney, 1980), by dividing the slope of the SPMD extract by the slope of TCDD, and correcting for the volume of extract and the g of SPMD (Ankley et al., 1991).

The expression of potency of the SPMD extracts as pg TCDD-EQ/g SPMD does not imply that the SPMDs contained TCDD. Rather, the compounds accumulated by the SPMDs were as potent as, or were equivalent to, a certain amount of TCDD. The polyethylene can act as a substantial reservoir for lipophilic chemicals because it is hydrophobic in nature. Thus, final concentrations of TCDD-EQ in the SPMDs were based on the entire weight of the sampling device, which included the triolein $(0.91 \mathrm{~g} / 1 \mathrm{~mL}$ SPMD) and the polyethylene tubing (4.01 g/1 SPMD).

\section{PAH Analysis of SPMD Extracts}

Prior to dosing fish cells, $100 \mu \mathrm{L}$ of the $1000 \mu \mathrm{L}$ isooctane SPMD extract was removed for chemical analyses. Identification and quantitative determinations of the PAHs were based on analysis on a HP-5MS capillary column. A Hewlett-Packard (HP) 5890 II gas chromatograph was coupled to a HP 5970 mass selective detector (MSD). The sample $(2 \mu \mathrm{L})$ was injected in splitless mode with a time delay of 1.25 minutes after injection. The initial oven temperature of $60^{\circ} \mathrm{C}$ was held for two minutes. The temperature was then programmed to increase in three stages: 1 ) by $10^{\circ} \mathrm{C} / \mathrm{min}$ to $150^{\circ} \mathrm{C} ; 2$ ) by $3^{\circ} \mathrm{C} / \mathrm{min}$ to $280^{\circ} \mathrm{C}$; and 3) by $10^{\circ} \mathrm{C} / \mathrm{min}$ to $300^{\circ} \mathrm{C}$. This final temperature was held for a further five minutes. The injector temperature was $250^{\circ} \mathrm{C}$, and that of the transfer line, was $280^{\circ} \mathrm{C}$. The carrier gas was helium, with an initial column head pressure of 15 psi. The system was equipped with Electronic Pressure Control (EPC) and operated in constant flow mode. The filament and the multiplier were turned on six minutes after injection. The system was operated in the SIM mode. Standard midmass autotunes using PFTBA were performed before each set of environmental samples was analysed.

The concentrations of PAHs were calculated by singlepoint calibration. For each set of environmental samples, the GC/MS instrument was calibrated using an external standard mix. A measured aliquot of the standard solution was injected into the column. The response of the GC to each analyte was the basis of the single-point calibration. An external standard mix was run after every 10 samples with the retention times and the responses updated. Stand- 


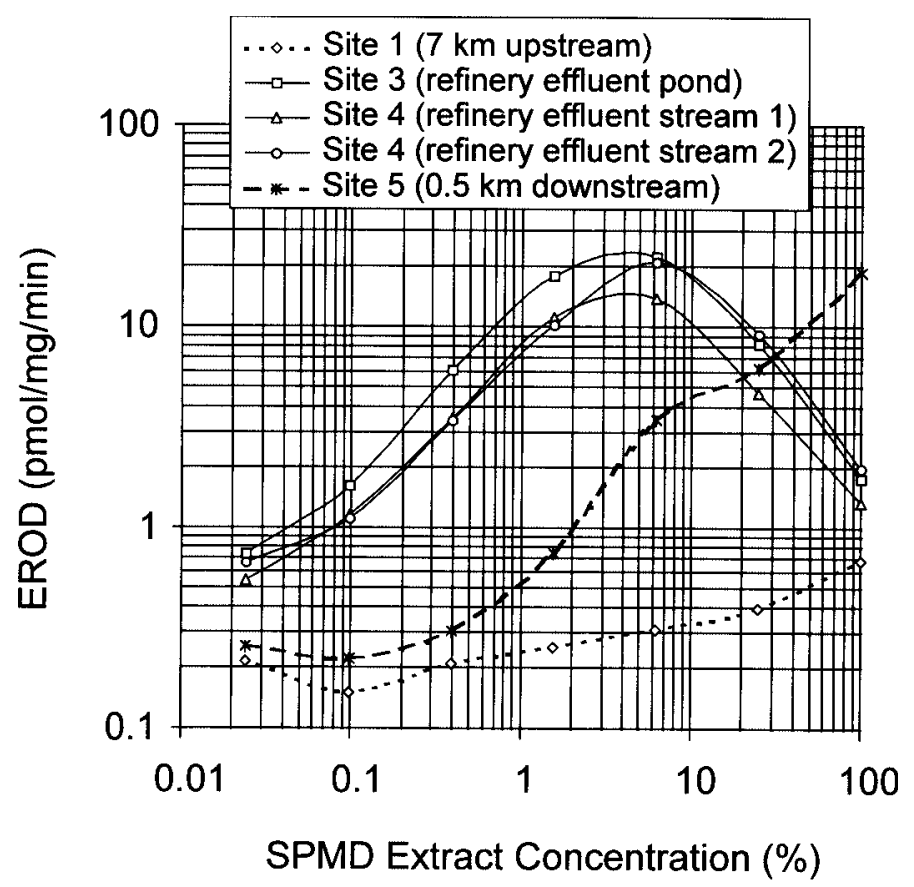

FIG. 3. EROD activity in PLHC-1 cells exposed for 72 hours to extracts of SPMDs from refinery effluent pond and effluent stream and from sites $7 \mathrm{~km}$ upstream and $0.5 \mathrm{~km}$ downstream on the Mackenzie River. Each point on the curve is the mean of three replicate wells of liver cells dosed with SPMD extract. SPMD extract concentration of $100 \%$ refers to $5 \mu \mathrm{L}$ (of the $1 \mathrm{~mL}$ extract from two SPMDs) dosed to $500 \mu \mathrm{L}$ of cell media. SPMD extract concentration of $10 \%$ refers to $0.5 \mu \mathrm{L}$ of SPMD extract dosed to $500 \mu \mathrm{L}$ of cell media, and so on.

ards were available for parent PAHs, but not for C1- to C3substituted derivatives. To calculate the concentrations of C1- to C3-substituted PAHs, peak areas were determined and parent $\mathrm{PAH}$ concentrations were used as relevant standard materials.

\section{RESULTS}

All SPMD extracts induced ethoxyresorufin-Odeethylase (EROD) activity in the PLHC-1 cells. Some extracts were very low in potency (with induction maxima of only $0.2-1.0 \mathrm{pmol} / \mathrm{mg}$ protein $/ \mathrm{min}$ ), while others in- duced the fish liver cells to over $20 \mathrm{pmol} / \mathrm{mg} / \mathrm{min}$ (Fig. 3). SPMDs from the refinery effluent pond and stream concentrated inducers, with induction maxima of $14-22 \mathrm{pmol} /$ $\mathrm{mg} / \mathrm{min}$ at about $6.25 \%$ extract (or $0.31 \mu \mathrm{L}$ of the $1 \mathrm{~mL}$ SPMD extract in $500 \mu \mathrm{L}$ of cell media; Fig. 3). Concentrations of SPMD extract above this level (25\% or $100 \%$ ) showed lower EROD activity, indicating that higher doses of extracts caused MFO inhibition or cell toxicity. Refinery effluent-exposed SPMD extracts were not as potent as TCDD; cells dosed with refinery SPMD extracts showed EROD maxima of about $20 \mathrm{pmol} / \mathrm{mg} / \mathrm{min}$, while cells dosed with TCDD showed EROD maxima of 50 to 80 $\mathrm{pmol} / \mathrm{mg} / \mathrm{min}$ (data not shown). For TCDD-dosed cells, the slope of the initial portion of the EROD response curve was $2.54 \mathrm{EROD} /(\mathrm{pg} \mathrm{TCDD} /$ well). Using this value to assess the slopes of extracts of SPMDs from the refinery pond and stream, we calculated the potency of the refinery SPMDs at 4830-8700 pg TCDD-EQ/g SPMD (Table 2). SPMD extracts from the refinery stream were about $60 \%$ the potency of SPMD extracts from the refinery pond.

Downstream of the refinery outfall, SPMD extracts concentrated MFO inducers, and dose response curves rose to maxima similar to those of the effluent SPMDs (about $20 \mathrm{pmol} / \mathrm{mg} / \mathrm{min}$ for $100 \%$ extract; Fig. 3). SPMD extracts from site $5(0.5 \mathrm{~km}$ downstream $)$ contained $143 \mathrm{pg}$ TCDD-EQ/g SPMD (Table 2), about 1/30 the potency of SPMDs from the refinery stream and $1 / 60$ the potency of those from the pond. Unfortunately, SPMDs from sites 6 and 7 ( 7 and $12 \mathrm{~km}$ downstream) were destroyed by turbulent currents, so the picture of MFO inducers in these areas is incomplete.

Trip blank SPMD extracts were low in potency, with EROD maxima of $0.4-1.3 \mathrm{pmol} / \mathrm{mg} / \mathrm{min}$ for $100 \%$ extract ( $5 \mu \mathrm{L}$ of the $1 \mathrm{~mL}$ of extract in $500 \mu \mathrm{L}$ of cell media; Fig. 4). Trip blank SPMDs had potencies equal to a few pg TCDD$\mathrm{EQ} / \mathrm{g}$ SPMD. Differences in potencies were seen among trip blank SPMD extracts from various sites: $9.2 \mathrm{pg}$ TCDDEQ/g SPMD for site 1; 1.4 for site 2; 5.0 for effluent sites; 7.2 for site $5 ; 3.0$ for site 6 ; and 4.6 for site 7 .

SPMDs from the Mackenzie River site 1 (7 km upstream of the refinery outfall) concentrated negligible quantities of inducers during the 12-day exposure. SPMDs

TABLE 2. Potencies of SPMDs from the Mackenzie River and from Norman Wells refinery effluent.

\begin{tabular}{|c|c|c|c|c|c|c|}
\hline Site & $\mathrm{km}$ & No. SPMDs & Days & $\begin{array}{c}\text { Slope }^{1} \\
\text { (EROD/(mL extract/well)) }\end{array}$ & $r^{2}$ & $\begin{array}{c}\text { Potency } \pm \text { SE } \\
(\text { pg TCDD-EQ/g SPMD })^{2}\end{array}$ \\
\hline 1 (upstream) & -7 & 1 & 12 & 0.0820 & 0.755 & $6.45 \pm 1.18$ \\
\hline 3 (effluent pond) & 0 & 2 & 11 & 221 & 0.917 & $8700 \pm 830$ \\
\hline 4 (effluent stream rep 1) & 0 & 2 & 11 & 136 & 0.977 & $5360 \pm 260$ \\
\hline 4 (effluent stream rep 2$)$ & 0 & 2 & & 123 & 0.836 & $4830 \pm 680$ \\
\hline 5 (downstream) & 0.5 & 2 & 12 & 3.64 & 0.980 & $143 \pm 4.7$ \\
\hline
\end{tabular}

${ }^{1}$ The initial linear slope of the dose response curve was calculated (EROD activity versus $\mu \mathrm{L}$ SPMD extract/well, $\mathrm{r}^{2}$ ).

${ }^{2}$ Slopes of SPMD extracts were compared to the slope for TCDD-exposed cells (EROD versus pg TCDD/well; slope = 2.542 EROD/ (pg TCDD/well), $\left.\mathrm{r}^{2}=0.990\right)$. Potency of each SPMD was expressed as pg TCDD-EQ/g SPMD \pm standard error. 


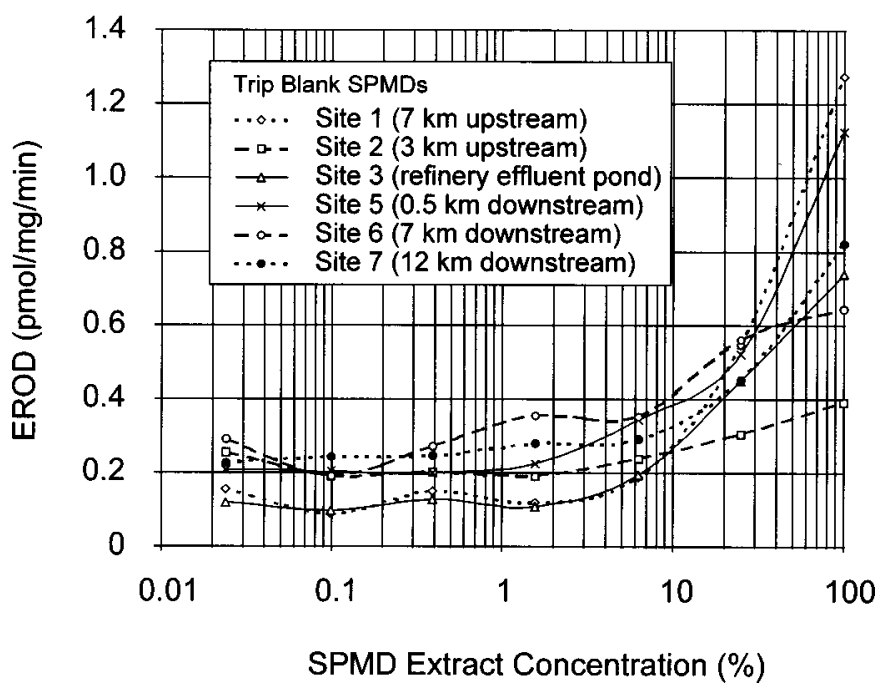

FIG. 4. EROD activity in PLHC-1 cells exposed for 72 hours to extracts of trip blank SPMDs exposed only to air and handling contamination. Each point on the curve is the mean of three replicate wells of liver cells dosed with SPMD extract. Note that EROD is on an arithmetic scale to enhance differentiation among trip blanks.

from site 1 upstream were very low in potency: The dose response curve (Fig. 3) and the calculated TCDD-equivalent potency (6.5 pg TCDD-EQ/g SPMD) were similar to those of unexposed trip blanks.

\section{Compounds Concentrated by SPMDs}

Many classes and sizes of PAHs and C1- to C3-substituted PAHs were detected in all SPMDs, whether exposed or trip blanks (Table 3). Concentrations of C1- to C3substituted PAHs were high in effluent-exposed SPMDs and in downstream SPMDs.

Trip blanks (unexposed SPMDs) contained low concentrations $(<65 \mathrm{ng} / \mathrm{mL})$ of naphthalene, C1- to C3naphthalene, phenanthrene and anthracene. One trip blank (site 1) contained $2000 \mathrm{ng} / \mathrm{mL}$ of total C2-chrysene, while for other trip blanks, chrysenes were not detectable. Site 5 trip blank had $62 \mathrm{ng} / \mathrm{mL}$ 9,10-dimethyl anthracene and 20 $\mathrm{ng} / \mathrm{mL}$ benzo(b,k)fluoranthene, while other trip blanks showed lower contamination levels.

PAHs and C1- to C3-substituted PAHs were abundant in SPMD extracts from the refinery outfall. In SPMDs exposed to Norman Wells effluent, the highest concentrations of PAHs were C2-phenanthrene/anthracene (5400$9300 \mathrm{ng} / \mathrm{mL}$ ) and C3-phenanthrene/anthracene (11000-17000 ng/mL). Chrysene and C1- and C2chrysene were also high $(3500-7000 \mathrm{ng} / \mathrm{mL})$, followed by pyrene $(1600-2000 \mathrm{ng} / \mathrm{mL})$ and benzo(a)pyrene (1100$1600 \mathrm{ng} / \mathrm{mL}$; Table 3).

Some of the larger, heavier PAHs, such as benzo[a]pyrene and perylene were found at high concentrations $(1100-1600 \mathrm{ng} / \mathrm{mL}$ and $540-800 \mathrm{ng} / \mathrm{mL}$, respectively) in effluent-exposed SPMDs, while not detected in SPMDs from upstream or downstream sites. Other large PAHs, such as indeno[1,2,3-c,d]pyrene, dibenz[a,h]anthracene and benzo[g,h,i]perylene were present at low concentrations (up to $8 \mathrm{ng} / \mathrm{mL}$ ) in SPMDs from the refinery effluent, and not detected in SPMDs from upstream and downstream sites.

Naphthalene, C1-naphthalenes, phenanthrene and fluoranthene showed a pattern of higher concentrations in upstream and downstream SPMDs compared to effluentexposed SPMDs. The concentrations of C2-naphthalenes were higher in downstream SPMDs than in upstream SPMDs or refinery effluent-exposed SPMDs. Concentrations of chrysene and C1-chrysene were very high (4500$7000 \mathrm{ng} / \mathrm{mL}$ ) in effluent-exposed SPMDs, and low $(130-160 \mathrm{ng} / \mathrm{mL})$ in downstream SPMDs. In contrast, concentrations of C2-chrysene were high (3500-6300 ng/ $\mathrm{mL}$ ) in effluent-exposed SPMDs and nearly as high (2400 $\mathrm{ng} / \mathrm{mL}$ ) in downstream SPMDs (Table 3).

Most compounds showed the typical pattern of concentrations: low in SPMD extracts from the upstream site, high in refinery outfall, and lower at the downstream site. The PAHs showing this pattern were $\mathrm{C} 2$ - and $\mathrm{C} 3$-phenanthrenes, pyrene, chrysene, $\mathrm{C} 1$ - and $\mathrm{C} 2$-chrysene, and benzo $(b, k)$ fluoranthene.

The concentrations and patterns of PAHs in extracts of SPMDs from the upstream site, from the effluent pond and streams, and from the downstream site were compared to their respective MFO-inducing potency. Linear regression showed that the concentrations of total C3-phenanthrene/ anthracene correlated extremely well $\left(r^{2}=0.97\right)$ to the calculated EROD-inducing potency of the SPMD extracts. The correlation for chrysene was not as good $\left(r^{2}=0.60\right)$.

\section{DISCUSSION}

\section{MFO-Induction Potency at Norman Wells}

MFO-inducing chemicals from the Mackenzie River and from oil refinery effluent were effectively concentrated by SPMDs. Fish cells exposed to extracts of SPMDs from refinery effluent had high EROD activities, and potencies of extracts were 4830-8700 pg TCDD-EQ/g SPMD (Fig. 5). Extracts of SPMDs from the refinery stream were about $60 \%$ the potency of extracts from the refinery pond, indicating the loss of some inducers as the stream flowed to the Mackenzie River. Extracts of SPMDs that had been deployed $0.5 \mathrm{~km}$ downstream of the refinery outfall were $1 / 40$ as potent as those exposed to undiluted effluent. The potency of extracts of SPMDs deployed upstream of the refinery outfall was very low (similar to trip blanks), and about 1/20 the potency of downstream SPMDs.

SPMDs from upstream of the Norman Wells oil refinery represented the low "background" Mackenzie River MFOinduction potency. Unfortunately only one upstream site (site 1) had intact SPMD samples, so it is unclear how much variability there was in upstream Mackenzie River sites. Nevertheless, Mackenzie River background induction potency was very low at $6.5 \mathrm{pg}$ TCDD-EQ/g SPMD, 
TABLE 3. PAHs and methyl, dimethyl and trimethyl PAHs in SPMD extracts. Reported concentrations of PAHs are in ng/mL in the 1 $\mathrm{mL}$ of extract derived from two SPMDs. Although site 1 had only one SPMD intact (one SPMD was punctured), the values in the table have been corrected to represent two SPMDs concentrated to $1 \mathrm{~mL}$.

\begin{tabular}{|c|c|c|c|c|c|c|c|c|c|c|}
\hline \multirow[t]{2}{*}{ PAHs } & \multicolumn{5}{|c|}{ Exposed SPMDs } & \multicolumn{5}{|c|}{ Blanks } \\
\hline & $\begin{array}{c}\text { Site } 1 \\
\text { (upstream) }\end{array}$ & $\begin{array}{c}\text { Site } 3 \\
\text { (effluent pond) }\end{array}$ & $\begin{array}{l}\text { Site } 4 \\
\text { (effluent stream) (effl } \\
\text { rep } 1\end{array}$ & $\begin{array}{l}\text { Site } 4 \\
\text { fluent stream) } \\
\text { rep } 2\end{array}$ & $\begin{array}{c}\text { Site } 5 \\
\text { (downstream) }\end{array}$ & Site 1 & Site 2 & Site 5 & Site 6 & Site 7 \\
\hline Naphthalene & 108 & 35 & 22 & 22 & 109 & 62 & 0 & 63 & 0 & 0 \\
\hline 2-Methylnaphthalene & 66 & 0 & 9.3 & 18 & 196 & 41 & 8.4 & 47 & 22 & 24 \\
\hline 1-Methylnaphthalene & 50 & 0 & 7 & 1.9 & 138 & 22 & 6 & 19 & 29 & 12 \\
\hline Total C1-naphthalene & 106 & 0 & 16 & 20 & 330 & 63 & 14 & 67 & 52 & 36 \\
\hline 2,6 \& 2,7-Dimethylnaphthalene & 48 & 210 & 16 & 30 & 485 & 22 & 2.5 & 18 & 0 & 0 \\
\hline 1,6-Dimethylnaphthalene & 80 & 280 & 18 & 44 & 789 & 25 & 0 & 17 & 5.6 & 0 \\
\hline 2,3-\& 1,4-Dimethylnaphthalene & 40 & 7.4 & 36 & 86 & 330 & 9.4 & 0 & 8.6 & 7.2 & 0 \\
\hline 1,5-Dimethylnaphthalene & 44 & 180 & 38 & 84 & 245 & 14 & 0 & 5.2 & 15 & 4.8 \\
\hline 1,2-Dimethylnaphthalene & 15.2 & 0 & 10 & 0 & 72 & 0 & 0 & 0 & 0 & 0 \\
\hline Total C2-naphthalene & 340 & 680 & 130 & 260 & 2255 & 130 & 17 & 120 & 80 & 41 \\
\hline 2,3,6-Trimethylnaphthalene & 66 & 2200 & 180 & 380 & 816 & 25 & 0 & 0 & 0 & 0 \\
\hline 2,3,5-Trimethylnaphthalene & 38 & 630 & 43 & 99 & 618 & 12 & 0 & 0 & 0 & 0 \\
\hline Total C3-naphthalene & 360 & 7100 & 460 & 1000 & 4900 & 210 & 0 & 0 & 0 & 0 \\
\hline Acenaphthylene & 2.6 & 30 & 5.4 & 2.8 & 0 & 0 & 0 & 0 & 0 & 0 \\
\hline Acenaphthene & 3.8 & 0 & 14 & 23 & 0 & 0 & 0 & 0 & 0 & 0 \\
\hline Fluorene & 44 & 33 & 13 & 7.6 & 92 & 9.2 & 0 & 0 & 0 & 0 \\
\hline Phenanthrene & 280 & 56 & 38 & 49 & 600 & 21 & 0 & 0 & 0 & 0 \\
\hline Anthracene & 0 & 12 & 9 & 14 & 1.7 & 0 & 0 & 0 & 0 & 0 \\
\hline 3-Methylphenanthrene & 52 & 420 & 20 & 17 & 310 & 4.9 & 0 & 0 & 0 & 0 \\
\hline 2-Methylphenanthrene & 66 & 520 & 62 & 21 & 380 & 6.2 & 0 & 0 & 0 & 0 \\
\hline 2-Methylanthracene & 28 & 16 & 14 & 8.9 & 15 & 22 & 0 & 0 & 0 & 0 \\
\hline 9/4-Methylphenanthrene & 80 & 620 & 140 & 150 & 600 & 5.2 & 0 & 1.9 & 0 & 0 \\
\hline 1-Methylphenanthrene & 106 & 250 & 160 & 180 & 660 & 5.3 & 0 & 0 & 0 & 0 \\
\hline 9-Methylanthracene & 8 & 0 & 4 & 1.4 & 2 & 0 & 0 & 0 & 0 & 0 \\
\hline Total C1-phenanthrene/anthracene & e 338 & 1800 & 400 & 380 & 1900 & 43 & 0 & 1.9 & 0 & 0 \\
\hline 3,6-Dimethylphenanthrene & 22 & 700 & 950 & 800 & 190 & 0 & 0 & 0 & 0 & 0 \\
\hline 9,10-Dimethylanthracene & 4 & 530 & 540 & 260 & 21 & 0 & 0 & 62 & 0 & 0 \\
\hline Total C2-phenanthrene/anthracene & le 260 & 9300 & 9000 & 5400 & 3500 & 0 & 0 & 62 & 0 & 0 \\
\hline Total C3-phenanthrene/anthracene & le 200 & 17000 & 11000 & 12000 & 2700 & 0 & 0 & 0 & 0 & 0 \\
\hline Fluoranthene & 112 & 58 & 68 & 19 & 340 & 0 & 0 & 0 & 0 & 0 \\
\hline Pyrene & 58 & 1700 & 2000 & 1600 & 200 & 0 & 0 & 0 & 0 & 0 \\
\hline Benz[a]anthracene & 0 & 0 & 0 & 0 & 0 & 0 & 0 & 0 & 0 & 0 \\
\hline Chrysene & 40 & 4500 & 7000 & 6600 & 130 & 0 & 0 & 0 & 0 & 0 \\
\hline Total C1-chrysene & 20 & 4400 & 4500 & 4700 & 160 & 0 & 0 & 0 & 0 & 0 \\
\hline Total C2-chrysene & 0 & 6300 & 3800 & 3500 & 2400 & 2000 & 0 & 0 & 0 & 0 \\
\hline Benzo[b,k]fluoranthene & 3.6 & 290 & 330 & 250 & 16 & 0 & 0 & 20 & 0 & 5.4 \\
\hline Benzo[a]pyrene & 0 & 1100 & 1600 & 1300 & 0 & 0 & 0 & 0 & 0 & 0 \\
\hline Perylene & 0 & 540 & 800 & 650 & 0 & 0 & 0 & 0 & 0 & 0 \\
\hline Indeno[1,2,3-c,d]pyrene & 0 & 4 & 7.6 & 3.6 & 0 & 0 & 0 & 0 & 0 & 0 \\
\hline Dibenz[a,h]anthracene & 0 & 5.2 & 2.6 & 0 & 0 & 0 & 0 & 0 & 0 & 0 \\
\hline Benzo[g,h,i]perylene & 0 & 5.1 & 3.6 & 3.1 & 0 & 0 & 0 & 0 & 0 & 0 \\
\hline
\end{tabular}

which was about half the average Athabasca River background induction potency (Parrott et al., 1996a). The Mackenzie River upstream site was clearly not a "hotspot" of seepage of PAHs, as induction potency was among the lowest seen in SPMDs deployed in Canadian rivers (unpublished data).

Extracts of SPMDs from the Norman Wells refinery had high potencies, in the same order of magnitude as extracts of SPMDs from oil sands wastewater ponds and from a stormwater-contaminated creek. SPMDs from Alberta oil sands wastewaters concentrated $16800 \mathrm{pg}$ TCDD-EQ/g SPMD in 14-day deployments during the summer of 1994 (Parrott et al., 1996a), compared to 8700 pg TCDD-EQ/g SPMD in this study (11-day deployment in the Norman Wells refinery pond). The potency of extracts of SPMDs from the Norman Wells oil refinery was about half that of 


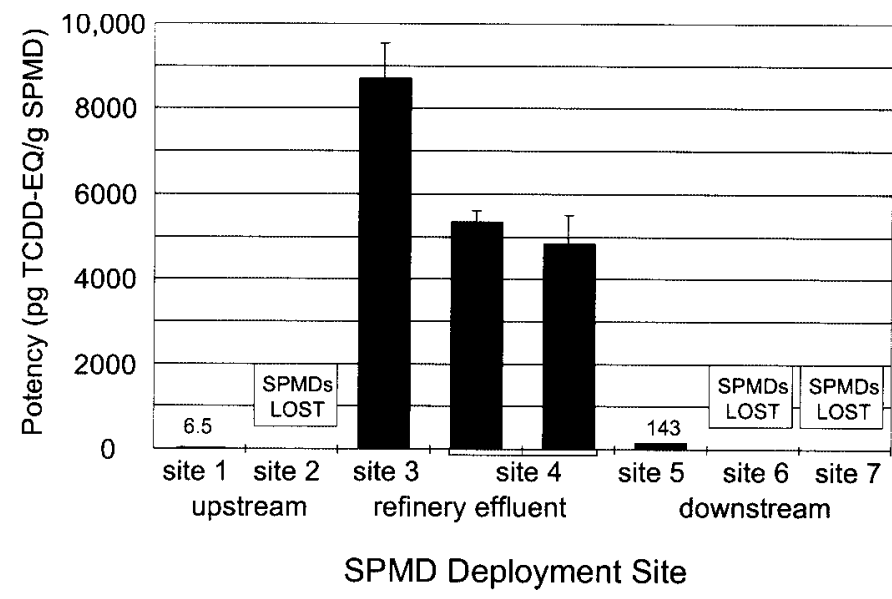

FIG. 5. Potency of SPMD extracts (pg TCDD-EQ/g SPMD \pm SE) for induction of EROD in fish liver cells. SPMDs were deployed at various Mackenzie River sites, and in effluent from the Norman Wells refinery. SPMDs from site 2 upstream, and from sites 6 and 7 downstream, were lost.

the oil sands wastewater-exposed SPMDs. SPMDs deployed for 14 days in Lincoln Creek, Milwaukee, which receives PAH-contaminated stormwater runoff, had 1300$6600 \mathrm{pg}$ TCDD-EQ/g SPMD (Villeneuve et al., 1997), a potency very similar to those of our SPMDs from Norman Wells refinery effluent.

\section{Factors Affecting Uptake of Inducers by SPMDs}

There were two major physical differences among SPMD deployment sites on the Mackenzie River and the refinery effluent ponds: water temperature and water flow rates. The river sites had a constant low temperature $\left(10-11^{\circ} \mathrm{C}\right)$, whereas the Norman Wells effluent temperature was very high $\left(48^{\circ} \mathrm{C}\right)$. These temperature differences may have influenced the uptake of PAHs by the SPMDs, but the magnitude of this effect is unknown. Huckins et al. (1995b) showed SPMD uptake of planar PAHs was only slightly influenced by water temperature. Some PAHs (phenanthrene, acenaphthylene and benzo[g,h,i]perylene) showed negligible changes in uptake rates, while others (benzo[a]pyrene and chrysene) showed 40-50\% higher uptake rates as water temperatures increased from 10 to $26^{\circ} \mathrm{C}$. It is unclear what effect the large temperature differences $\left(10^{\circ} \mathrm{C}\right.$ to $\left.48^{\circ} \mathrm{C}\right)$ would have had on the uptake of MFO inducers by SPMDs. The probable effect would be an increased absorption at high temperatures, which would magnify observed difference in potencies.

Flow rates also differed among sites on the Mackenzie River and in the oil refinery effluent, and this factor has recently been found to influence SPMD uptake of chemicals. Uptake is thought to be controlled by the aqueous diffusion layer (Huckins et al., 1997), with a thicker diffusion layer and slower uptake in low-flow situations. Phenanthrene transfer through a semipermeable membrane was $50 \%$ slower when flow decreased 50-fold, from 0.2 to $0.004 \mathrm{~cm} / \mathrm{sec}$ (Huckins et al., 1997). PAH uptake into SPMDs under low-flow conditions $(0.03 \mathrm{~cm} / \mathrm{sec})$ was
$1 / 3$ that of SPMDs under high-flow conditions $(30 \mathrm{~cm} / \mathrm{sec}$ ) (Booij et al., 1998).

Although flow can affect the thickness of the diffusion layer and chemical uptake by SPMDs, it appears that such influence is limited: water flow rates that differed by three orders of magnitude showed only two- to threefold differences in PAH uptake by SPMDs. SPMDs deployed in the Mackenzie River and refinery effluent were subject to high flow rates, so the influence of different water flows on chemical uptake by our Mackenzie River SPMDs is thought to be limited.

Regardless of the influence of these uncontrollable physical parameters on the uptake of chemicals by SPMDs, the SPMDs performed extremely well under harsh conditions of high flow and high temperature. The difference in SPMD potencies for MFO induction in the fish cell line spanned orders of magnitude: refinery effluent-exposed SPMDs contained over 1300 times the potency of upstream SPMD extracts. Thus, while temperature (and perhaps flow) differences among sites may have slightly affected uptake of compounds by SPMDs, the huge differences in potencies cannot be explained away by the influence flow and temperature differences may have had on membrane uptake kinetics.

\section{Compounds Concentrated by SPMDs}

Polyaromatic hydrocarbons (PAHs) and C1- to C3substituted PAHs were abundant in SPMDs from the refinery effluent and from downstream sites. Among SPMDs from various sites, there were differences in the concentrations of PAHs, as well as in the patterns of parent PAHs and $\mathrm{C} 1-, \mathrm{C} 2$-and $\mathrm{C} 3$-substituted derivatives. The importance of measuring the $\mathrm{C} 1-, \mathrm{C} 2$ - and $\mathrm{C} 3$-substituted PAHs was obvious: concentrations of substituted-PAHs dominated the chemical profiles of the SPMDs. Ratios of these substituted PAHs give information about the source of the PAH, whether petrogenic or combustion.

The pattern of parent PAHs and $\mathrm{C} 1, \mathrm{C} 2$ - and $\mathrm{C} 3$ substituted PAHs differed from site to site. Upstream SPMDs contained low concentrations of PAHs, and their concentrations of parent PAHs were very similar to concentrations of substituted PAHs (C1- to C3-naphthalene, $\mathrm{C} 1$ - to $\mathrm{C} 3$-phenanthrene/anthracene and $\mathrm{C} 1$ - to $\mathrm{C} 2$ chrysene). This profile differed markedly from that of the effluent-exposed SPMDs, which contained high concentrations of PAHs and had concentrations of C2- and C3derivatives that were many times those of parent PAHs. This difference in PAH profiles suggested that upstream of the refinery the PAH source was different, and PAHs may have been derived from atmospheric input of combustion sources.

Upstream of the refinery input, the low concentrations of PAHs and patterns of PAHs in the SPMD extracts suggest limited "natural" PAH input to the Mackenzie River from weathering of oil-rich substrates, diverse upstream sources, or atmospheric input. Generally, PAH 
concentrations upstream of the refinery input were quite low, and in the neighbourhood of the trip blank contamination. PAHs that were present in upstream SPMDs in higher quantities (over 10-fold greater) than trip blanks were C3-phenanthrene/anthracene, fluoranthene, pyrene, chrysene and $\mathrm{C} 1$-chrysene, and phenanthrene.

SPMDs downstream of the refinery outfall had higher concentrations of PAHs and C1-, C2- and C3-substituted PAHs than extracts of SPMDs from the upstream site. Concentrations of naphthalene in downstream SPMDs (versus upstream SPMDs) showed a pattern of C1- to C3-naphthalene enrichment downstream (3-fold for C1naphthalene, 7-fold for $\mathrm{C} 2$-naphthalene, and over 13-fold for C3-naphthalene). Concentrations of C1- to C3-phenanthrene/anthracene showed a similar pattern of enrichment downstream (5-fold for $\mathrm{C} 1$ - and 13-fold for C2- and C3-) versus upstream. This pattern suggested a petrogenic origin rather than combustion sources (Bouloubassi and Saliot, 1991; Yunker and MacDonald, 1995).

Generally, oil-derived PAHs show a typical profile of higher concentrations of $\mathrm{C} 1-, \mathrm{C} 2-$, and $\mathrm{C} 3$-substituted PAHs, compared to concentrations of parent PAHs (Bouloubassi and Saliot, 1991). The low temperature formation of petroleum favours PAHs with a higher degree of alkylation and $\mathrm{PAH}$ profiles that peak at the $\mathrm{C} 2-$ or $\mathrm{C} 3-$ substitution: concentrations of $\mathrm{C} 2$ - and C3-phenanthrenes in bunker oil were much greater than those of $\mathrm{C} 1$ phenanthrene and phenanthrene. In contrast, pyrolysis and combustion PAH sources favour the dominance of unsubstituted PAHs, with lower concentrations of C1-, C2-, and C3-substituted PAHs (Bouloubassi and Saliot, 1991).

Some PAHs were actually lower in SPMD extracts from the refinery effluent than in those from upstream and downstream sites on the Mackenzie River. Naphthalene, C1-naphthalene, phenanthrene, and fluoranthene were higher in SPMDs from upstream and downstream sites, and C2-naphthalene was higher in SPMDs from the downstream site, compared to SPMDs from the refinery effluent ponds. This observation suggests that these PAHs were ubiquitous in the Mackenzie River, and were not associated with input from the refinery. Indeed, the high temperatures of the refinery effluent may facilitate the evaporative loss of these PAHs, so that the concentrations in effluent were actually lower than concentrations upstream.

Extracts of SPMDs from the refinery effluent and streams contained the highest concentrations of most of the measured PAHs. Some of the small PAHs (C3-naphthalene and C1- to C3-phenanthrenes) most of the four-ring PAHs (pyrene, chrysene and C1- and C2-chrysene), and all of the five- and six-ring PAHs (benzo[b,k]fluoranthene, benzo[a]pyrene, perylene, indeno[1,2,3-c,d]pyrene, dibenz $[\mathrm{a}, \mathrm{h}]$ anthracene and benzo[g,h,i]perylene) showed the expected pattern: concentrations were higher in extracts of SPMDs from effluent than in those from downstream or upstream sites. Several of these larger PAHs (indeno[1,2,3-c,d]pyrene, dibenz[a,h]anthracene, and benzo[g,h,i]perylene) were detected at low levels $(<8 \mathrm{ng} /$ $\mathrm{mL}$ ) in SPMDs from the effluent pond and streams, and were below detection in extracts of SPMDs from upstream or downstream sites.

Comparing the chemical compositions of extracts of SPMDs from the refinery effluent ponds and those from the site $0.5 \mathrm{~km}$ downstream, we see that for many PAHs the concentrations in SPMDs from effluent were similar to (within 3-fold of) those downstream. A few PAHs were much higher in extracts from effluent than in extracts from downstream sites. The PAHs that were relatively higher in effluent were anthracene, C3-phenanthrene/anthracene, pyrene, and particularly chrysene, C1-chrysene, benzo[b,k]fluoranthene, benzo[a]pyrene, and perylene. This pattern differed from that measured in SPMDs exposed to oil sands wastewater, where the main PAH found was pyrene (over $20000 \mathrm{ng} / \mathrm{mL}$ SPMD extract; Parrott et al., 1996b). However, other predominant PAHs in SPMDs from oil sands wastewater (benzo[a]pyrene, benzo[b,k] fluoranthene, and fluoranthene, at concentrations of about $100-1000 \mathrm{ng} / \mathrm{mL}$ SPMD extract) were similar to SPMDs from Norman Wells refinery effluent.

SPMDs from Norman Wells oil refinery effluent contained similar PAHs to SPMDs from Lincoln Creek, Milwaukee, a "severely impaired" stream that receives stormwater runoff. Lincoln Creek SPMD extracts contained high concentrations of fluoranthene, pyrene, chrysene, phenanthrene, and benzo[b,k]fluoranthene (780$4900 \mathrm{ng} / \mathrm{g}$ triolein; Villeneuve et al., 1997). Normalizing the Villeneuve et al. (1997) data to two SPMDs in $1 \mathrm{~mL}$ of extract, these concentrations were about 1560-9800 ng/ $\mathrm{mL}$. Concentrations of pyrene and chrysene were similar in SPMDs from Lincoln Creek stormwater and from Norman Wells effluent. However, Norman Wells SPMDs showed lower concentrations of fluoranthene, phenanthrene, and benzo[b,k]fluoranthene than the stormwater-exposed SPMDs. Unfortunately, because concentrations of C1- to C3-substituted PAHs were not measured in SPMDs from Lincoln Creek stormwater, comparisons cannot be made for the substituted PAHs.

\section{The Nature of the Inducer}

It is not known which compounds in SPMDs from Norman Wells refinery effluent caused the observed MFO induction in fish liver cells. The listed PAHs and substituted PAHs (Table 3 ) were the only compounds quantified in the SPMDs, and undoubtedly the SPMDs contained hundreds of compounds, including other PAHs and substituted PAHs, PCBs, organochlorine pesticides, and chemicals lumped in the category of "unknowns."

Classical MFO inducers are chlorinated dibenzo- $p$ dioxins, furans, and PCBs, as well as certain PAHs, such as benzo[a]pyrene. SPMDs from the refinery effluent contained benzo[a]pyrene, but this compound was not detected in downstream SPMDs. So, while benzo[a]pyrene 
may have contributed to the induction seen in refinery SPMD extracts, it was not responsible for the significant induction in downstream SPMD extracts.

The pattern of potencies of induction in SPMDs from the upstream site, the refinery effluent pond, the effluent stream, and the site $0.5 \mathrm{~km}$ downstream (Fig. 5) was mirrored by concentrations of certain PAHs in SPMD extracts. One PAH group in particular, total C3phenanthrene/anthracene, showed a remarkable fit: concentrations of total C3-phenanthrene/anthracene in SPMD extracts correlated to the SPMD fish cell ERODinducing potencies with an $\mathrm{r}^{2}$ of 0.97 . This does not prove that these compounds caused the observed induction, but they are certainly candidates. No other measured PAH showed such a good fit of concentration to induction potency: the correlation for chrysene had an $\mathrm{r}^{2}$ of 0.60 . There were no detectable C3-phenanthrene/ anthracene in extracts of trip blank SPMDs, although some trip blanks showed slight induction. So while there is very good correlation between C3-phenanthrene/ anthracene and induction in exposed SPMDs, it cannot explain the very slight differences in potencies among trip blanks.

Di-, tri- and tetra-methylated phenanthrenes induced MFO in fish and fish cells (Parrott et al., 1995b). Rainbow trout (Oncorhynchus mykiss) hepatic MFO was induced by 3,6-dimethyl phenanthrene and 1-methyl-7-isopropyl phenanthrene (retene), so some of the C2- or C3-phenanthrenes in refinery SPMD extracts may be MFO-inducers. Retene induced EROD in PLHC1 at concentrations of about 30-600 ng/well. Extracts of SPMDs from Norman Wells refinery effluent contained 11000-17 000 ng/mL total C3-phenanthrene/ anthracene. Maximum EROD at $6.25 \%$ would equate to concentrations of total C3-phenanthrene/anthracene of only 3.4-5.3 ng/well. Assuming all total trimethyl phenanthrenes or anthracenes were equipotent to retene, it appears that these compounds alone could not account for the induction seen. It is unknown how much C4-phenanthrene was in refinery-exposed SPMDs. If the observed trend continued, with increasing concentrations from phenanthrene $(38-56 \mathrm{ng} / \mathrm{mL})$ to $\mathrm{C} 1$ phenanthrene $(380-1800 \mathrm{ng} / \mathrm{mL})$ to $\mathrm{C} 2$-phenanthrene $(5400-9300 \mathrm{ng} / \mathrm{mL})$ to $\mathrm{C} 3$-phenanthrene $(11000-$ $17000 \mathrm{ng} / \mathrm{mL}$ ), it is not unreasonable to predict high concentrations of $\mathrm{C} 4$-phenanthrene. If this is the case, the observed EROD induction in extracts of SPMDs from Norman Wells refinery effluent may have been due to the unmeasured $\mathrm{C} 4$-phenanthrene components, or to the combined effects of C3-and C4-phenanthrenes.

Chrysene, C1-, and C2-chrysene were another group of prominent PAHs identified in SPMDs exposed to Norman Wells effluent. It is unknown how potent these compounds are as MFO inducers in PLHC-1. Chrysene $(30 \mathrm{mg} / \mathrm{kg}$, i.p. injected) induced MFO in rainbow trout (Gerhart and Carlson, 1978), so it is a probable inducer in PLHC-1. Knowledge of other PAHs and their $\mathrm{C} 1-$ and $\mathrm{C} 2-$ derivatives suggests that $\mathrm{C} 1$ - and $\mathrm{C} 2$-chrysenes may also induce MFO in PLHC-1. Correlation of the concentrations of chrysene in SPMD extracts to their MFO-induction potency showed an $\mathrm{r}^{2}$ of 0.60 , which was not as good a fit as that seen for total C3-phenanthrene/anthracene.

Extracts of SPMDs exposed for 14 days to Lincoln Creek stormwater were close in potency to extracts of SPMDs from the oil refinery effluent in the present study (1300-6600 pg TCDD-EQ/g SPMD; Villeneuve et al., 1997). However, mixtures of 15 priority parent PAHs were able to explain only $20-50 \%$ of the EROD induction potency in the Villeneuve et al. (1997) stormwaterexposed SPMDs. The abundance of C1- to C3-substituted PAHs in the Norman Wells SPMDs indicates that substituted PAHs may have been present in the stormwaterexposed SPMDs, and these may have accounted for some of the observed induction in PLHC-1 in the Villeneuve et al. (1997) study.

\section{Sensitivity of the Fish Cell MFO-Induction Assay}

The sensitivity of the fish cell line to MFO inducers was demonstrated by the slight induction seen in cells exposed to extracts of unexposed SPMD trip blanks. Chemicals present in trip blanks may have been present in the manufactured SPMDs or could have been introduced during deployment (handling) or clean-up of SPMDs. According to the chemistry data for the trip blanks (Table 3), the least contaminated trip blanks were from site 2 , and the most contaminated trip blanks were from sites 1 and 5. This result agrees with the fish cell MFO response. For PLHC1 MFO-induction potency (Fig. 4), as judged by EROD activity at $100 \%$ extract concentration and slopes of doseresponse curves, the least potent trip blanks were those from site 2, while the trip blanks containing the most MFO inducers were from sites 1 and 5. The fish cell MFO responses agree with the chemical data: trip blanks from sites 1 and 5 were the most contaminated, while trip blanks from site 2 were the cleanest. Although differences in potency within trip blanks were observed, the potencies of trip blanks were very low compared to the potencies of wastewater-exposed SPMDs or downstream SPMDs.

Fish cells responded to extremely minute quantities of the SPMD extracts. Most potent induction was seen in extracts of SPMDs from the oil refinery pond and stream, at cell-exposure concentrations of about $5 \%$. This corresponded to $0.25 \mu \mathrm{L}$ of SPMD extract dosed to $500 \mu \mathrm{L}$ of cell media in each well. Two SPMDs $(10 \mathrm{~g}$ SPMD) provided $1000 \mu \mathrm{L}$ of extract. The minute amounts needed to dose the cells provided ample extract for repeated dosing, as well as for chemical analyses and future manipulation or investigation of the SPMD extracts. The use of SPMDs in conjunction with sensitive bioassays has potential application in toxicity identification and evaluation (TIE) schemes, to assess bioactive fractions and identify chemicals causing biological effects. 


\section{CONCLUSIONS}

SPMDs were successful in concentrating chemicals from the Mackenzie River and from Norman Wells oil refinery effluent. Chemicals in the extracts induced MFO in the fish liver cell line, PLHC-1. Upstream sites had negligible potency, while refinery effluent-exposed SPMDs were equivalent to 4380-8700 pg TCDD-EQ/g SPMD. Downstream of the effluent input, SPMDs contained 1/40 the potency of those exposed to the effluent, and over 20 times the potency of upstream SPMDs. Concentrations of PAHs in extracts of SPMDs varied among sites. The most prevalent compounds in effluent-exposed SPMDs and downstream SPMDs were C1- and C2-naphthalenes, C3-, C2-, and C1-phenanthrene/anthracene, pyrene, chrysene, $\mathrm{C} 1$ - and $\mathrm{C} 2$-chrysene, benzo[b,k]fluoranthene, benzo[a]pyrene, and perylene. In effluent-exposed SPMDs and in downstream SPMDs, C1- to C3-phenanthrene was more prevalent than parent phenanthrene, suggesting a petrogenic origin. In upstream SPMDs, concentrations of C1- to C3-substituted PAHs were extremely low, and were similar to concentrations of parent PAHs, suggesting combustion/atmospheric PAH input at site 1. It is unknown which of the compounds in the SPMDs were responsible for the observed MFO induction in fish liver cells. Candidate compounds were $\mathrm{C} 3$-phenanthrene/anthracene, pyrene, chrysene, and C1- and C2-chrysene. Of these, the concentration of total C3-phenanthrene/anthracene in the SPMD extracts correlated extremely well with the observed MFO-induction potency (TCDD-equivalents) in the extracts. The results showed that in harsh environments, SPMDs were useful concentrators of PAHs from a refinery effluent source. Coupled with a sensitive bioassay such as MFO in cell lines, the technique holds promise for toxicity identification and evaluation, and for assessment of contamination at remote sites.

\section{ACKNOWLEDGEMENTS}

We gratefully thank Mr. Steve Deschene, Department of Indian Affairs and Northern Development, Norman Wells and Mr. Barney Masuzumi, Renewable Resource Manager, Fort Good Hope for their help in the field. Thanks also to Mr. Jack Symes of the Environmental Section of the Norman Wells refinery for assisting with deployments in the refinery, and to Mr. Glen Stephens, Department of Indian and Northern Development, Yellowknife, for advice and for continued support of the project. We thank three anonymous reviewers for their comments on the manuscript.

\section{REFERENCES}

ANKLEY, G.T., TILLITT, D.E., GIESY, J.P., JONES, P.D., and VERBRUGGE, D.A. 1991. Bioassay-derived 2,3,7,8tetrachlorodibenzo- $p$-dioxin equivalents in the flesh and eggs of Lake Michigan chinook salmon and possible implications for reproduction. Canadian Journal of Fisheries and Aquatic Sciences 48:1685-1690.

BOOIJ, K., SLEIDERINK, H.M., and SMEDES, F. 1998. Calibrating the uptake kinetics of semipermeable membrane devices using exposure standards. Environmental Toxicology and Chemistry 17:1236-1245.

BOULOUBASSI, I., and SALIOT, A. 1991. Composition and sources of dissolved and particulate PAH in surface waters from the Rhone Delta (NW Mediterranean). Marine Pollution Bulletin 22(12):588-594.

FINNEY, D.J. 1980. Statistical methods in biological assay. London: Charles Griffin. 333 p.

GERHART, E.H., and CARLSON, R.M. 1978. Hepatic mixed function oxidase activity in rainbow trout exposed to several polycyclic aromatic compounds. Environmental Research 17:284-295.

GREENLEE, W.F., and POLAND, A. 1978. TCDD: A molecular probe for investigating the induction of aryl hydrocarbon hydroxylase. In: Cattabeni, F., Cavallaro, A., and Galli, G., eds. Monographs of the Giovanni Lorenzini Foundation. Vol. 1. Dioxin: Toxicology and chemical aspects. New York: SP Medical \& Scientific Books. 113-122.

HUCKINS, J.N., TUBERGEN, M.W., and MANUWEERA, G.K. 1990. Semipermeable membrane devices containing model lipid: A new approach to monitoring the bioavailability of lipophilic contaminants and estimating their bioconcentration potential. Chemosphere 20:533-552.

HUCKINS, J.N., LEBO, J.A., PETTY, J.D, ORAZIO, C.E., GIBSON, V.L., and HO, K. 1995a. Investigations into methods of removing from marine sediments that toxicity attributable to organic contaminants. Poster presented at 2nd SETAC World Congress, November 5-9, 1995, Vancouver, British Columbia.

HUCKINS, J.N., PETTY, J.D., ORAZIO, C.E., LEBO, J.A., GIBSON, V.L., and CLARK, R.C. 1995b. Effects of temperature, concentration and biofouling on semipermeable membrane device (SPMD) sampling rates in water. Poster presented at 2nd SETAC World Congress, November 5-9, 1995, Vancouver, British Columbia.

HUCKINS, J.N., PETTY, J.D., LEBO, J.A., ORAZIO, C.E., PREST, H.F., TILLITT, D.E., ELLIS, G.S., JOHNSON, B.T., and MANUWEERA, G.K. 1996. Semipermeable membrane devices (SPMDs) for the concentration and assessment of bioavailable organic contaminants in aquatic environments. In: Ostrander, G.K., ed. Techniques in aquatic toxicology. Boca Raton, Florida: CRC Press. 704 p.

HUCKINS, J.N., PETTY, J.D., PREST, H.F., LEBO, J.A., ORAZIO, C.E., GALE, R.D., and CLARK, R.C. 1997. Overview of SPMD technology for assessment of bioavailable organic compounds: Approaches, environmental variables, and data interpretation. Poster presented at 18th SETAC Annual Meeting, November 16-20, 1997, San Francisco, California.

JOHNSON, B.T. 1995. Collection and detection of petroleum products from air, water, and sediment: SPMDs and Microbics toxicity test systems as a screening tool. Presented at 3rd Annual SPMD Workshop and Symposium, June 13-15, 1995, Columbia, Missouri. 
JOHNSON, T., HUCKINS, J., PETTY, J., and BUTORIN, A. 1995. Rapid collection, detection, and assessment of environmental polycyclic aromatic hydrocarbons (PAHs). Poster presented at 2nd SETAC World Congress, November 5-9, 1995, Vancouver, British Columbia.

LOCKHART, W.L., METNER, D.A., MURRAY, D.A.J., and MUIR, D.C.G. 1987. Hydrocarbons and complaints about fish quality in the Mackenzie River, Northwest Territories, Canada. Water Pollution Research Journal of Canada 22:616-628.

LOCKHART, W.L., DUNCAN, D.A., BILLECK, B.N., DANELL, R.A., and RYAN, M.J. 1996. Chronic toxicity of the "watersoluble fraction" of Norman Wells crude oil to juvenile fish. Spill Science and Technology Bulletin 3:259-262.

LORENZEN, A., and KENNEDY, S.W. 1993. A fluorescencebased protein assay for use with a microplate reader. Analytical Biochemistry 214:346-348.

MARTIN, D.W., Jr., MAYES, P.A., RODWELL, V.W., and GRANNER, D.K. 1985. Harper's review of biochemistry. 20th. ed. Los Altos, California: Lange Medical Publications. 718 p.

METCALFE, T.L., WHITE, P., MACKAY, D., and METCALFE, C. 1995. Development of bioassay techniques with extracts from semi-permeable membrane devices (SPMDs). Poster presented at 2nd SETAC World Congress, November 5-9, 1995, Vancouver, British Columbia.

MUNKITTRICK, K.R., PORTT, C.B., VAN DER KRAAK, G.J., SMITH, I.R., and ROKOSH, D.A. 1991. Impact of bleached kraft mill effluent on population characteristics, liver MFO activity, and serum steroid levels of a Lake Superior white sucker (Catostomus commersoni) population. Canadian Journal of Fisheries and Aquatic Sciences 48:1371-1380.

OKEY, A.B. 1990. Enzyme induction in the cytochrome P-450 system. Pharmacology and Therapeutics 45:241-298.

PARROTT, J.L., HODSON, P.V., SERVOS, M.R., HUESTIS, S.L., and DIXON, D.G. 1995a. Relative potency of polychlorinated dibenzo- $p$-dioxins and dibenzofurans for inducing mixed function oxygenase activity in rainbow trout. Environmental Toxicology and Chemistry 14:1041-1050.

PARROTT, J.L., BURNISON, B.K., HODSON, P.V., COMBA, M.E., and FOX, M.E. 1995b. Substituted phenanthrenes as inducers of hepatic mixed function oxygenase (MFO) in rainbow trout (Oncorhynchus mykiss). Proceedings of the 21st Annual Aquatic Toxicity Workshop, October 3-5, 1994, Sarnia, Ontario. Canadian Technical Report of Fisheries and Aquatic Sciences No. 2050.
PARROTT, J.L., HODSON, P.V., TILLITT, D.E., BENNIE, D.T., and COMBA, M.E. 1996a. Accumulation of fish mixed function oxygenase inducers by semipermeable membrane devices in river water and effluents, Athabasca River, August and September, 1994. Northern River Basins Study Technical Report No. 83.

PARROTT, J.L., WHYTE, J.J., BACKUS, S.M., and COMBA, M.E. 1996b. Accumulation of fish mixed function oxygenase inducers by semipermeable membrane devices in river water and effluents, Athabasca, Peace and Wapiti Rivers, August and September, 1995. Northern River Basins Study Technical Report No. 127.

PARROTT, J.L., CHONG-KIT, R., and ROKOSH, D.A. 1999. MFO induction in fish: A tool to measure environmental exposure. In: Rao, S., ed. Impact assessment of hazardous aquatic contaminants: Concepts and approaches. Chelsea, Michigan: Ann Arbor Press, Inc. 99-122.

PAYNE, J.F., FANCEY, L.L., RAHIMTULA, A.D., and PORTER, E.L. 1987. Review and perspective on the use of mixed-function oxygenase enzymes in biological monitoring. Comparative Biochemistry and Physiology 86C:233-245.

POLAND, A., and KNUTSON, J.C. 1982. 2,3,7,8-Tetrachlorodibenzo-p-dioxin and related halogenated aromatic hydrocarbons: Examination of the mechanism of toxicity. Annual Review of Pharmacology and Toxicology 22:517-554.

PREST, H.F., HUCKINS, J.N., PETTY, J.D., HERVE, S., PAASIVIRTA, J., and HEINONEN, P. 1995. A survey of recent results in passive sampling of water and air by semipermeable membrane devices. Marine Pollution Bulletin 31:306-312.

ROHR, A.C., HALL, E.R., and HALL, K.J. 1996. Use of semipermeable membrane devices for monitoring pulp mill effluents: A preliminary assessment. Water Quality Research Journal of Canada 1:85-100.

TILLITT, D.E., GIESY, J.P., and ANKLEY, G.T. 1991. Characterization of the H4IIE rat hepatoma cell bioassay as a tool for assessing toxic potency of planar halogenated hydrocarbons in environmental samples. Environmental Science and Technology 25:87-92.

VILLENEUVE, D.L., CRUNKILTON, R.L., and DEVITA, W.M. 1997. Aryl hydrocarbon receptor-mediated toxic potency of dissolved lipophilic organic contaminants collected from Lincoln Creek, Milwaukee, Wisconsin, USA, to PLHC-1 (Poeciliopsis lucida) fish hepatoma cells. Environmental Toxicology and Chemistry 16:977-984.

YUNKER, M.B., and MACDONALD, R.W. 1995. Composition and origins of polycyclic aromatic hydrocarbons in the Mackenzie River and on the Beaufort Sea shelf. Arctic 48:118-129. 